кандидат экономических наук, доцент кафедры политической экономии и истории экономической науки Российского экономического университета им. Г.В. Плеханова

\section{ИНСТИТУТЫ УПРАВЛЕНИЯ ВЗАИМОДЕЙСТВИЕМ ПУБЛИЧНЫХ И ЧАСТНЫХ ПАРТНЕРОВ ПРИ РЕАЛИЗАЦИИ ИНФРАСТРУКТУРНЫХ ПРОЕКТОВ}

\section{Аннотация:}

В статье рассматриваются условия реализации и направления деятельности центров управления проектами государственно-частного партнерства (ГЧП). Изучен опыт ряда стран, имеющих наиболее успешные практики, а также стран, близких к России по экономическим условиям. Выявлены закономерности формирования и функционирования агентств, осуществляющих управле ние ГЧП. Показано, что наиболее развитые страны, добившиеся успехов в развитии ГЧП, переходят в управлении партнерствами от многофункциональных к консультационным агентствам. Рассмотрены организации, управляющие взаимодействием публичных и частных партнеров в России. Сделано предположение, что инициативы правительства по формированию Координационного межотраслевого совета по вопросам ГЧП и фабрики проектного финансирования позволят создать в России многофункциональное ГЧП-агентство. Представлен перечень основных услуг, которые должно осуществлять означенное агентство.

Ключевые слова:

государственно-частное партнерство, инфраструктура, агентство государственно-частного партнерства, финансирование проектов государственно-частного партнерства, фабрика проектного финансирования.
PhD in Economics, Assistant Professor, Department of Political Economy and History of Economics,

Plekhanov Russian University of Economics

\section{INSTITUTIONS MANAGING INTERACTION BETWEEN PUBLIC AND PRIVATE PARTNERS WHILE IMPLEMENTING THE INFRASTRUCTURE PROJECTS}

Summary:

The article reviews the terms for the implementation and the fields of concern of the PPP project management centers. The paper examines the experience of several countries that demonstrate the most successful practices and whose economic conditions are similar to Russia. The formation and functional patterns of the PPP management agencies are revealed. The study shows that the most developed countries that have made progress in the development of PPP are switching from multi-functional agencies to consulting ones. The organizations managing the interaction between public and private partners in Russia are considered. It is assumed that the government's initiatives on the formation of the PPP Coordinating Interdisciplinary Council and the project financing factory can lead to the creation of a multi-functional PPP agency in Russia. The author presents a list of essential services to be provided by the created agency.

Keywords: public-private partnership, infrastructure, public-private partnership agency, PPP projects financing, project financing factory.

Отношения сотрудничества между государством и частными предпринимателями существовали с момента появления государства, но только в 80-е гг. XX в. они стали проникать в такие сфреры экономики, которые ранее считались прерогативой государства и в которых шло формирование активов, производящих инфраструктурные услуги [1, с. 45]. Для разрешения проблем взаимодействия публичных и частных партнеров в этой сфере правительства многих стран пошли по пути создания специализированных органов управления государственно-частными партнерствами (ГЧП), для которых в мировой теории и практике отсутствует общепринятое название. В разных странах используют термины: «агентство», «центр», «департамент», «отдел». В первое десятилетие XXI в. более 25 национальных и региональных правительств создали подобные организации [2, р. 5].

Для анализа возможностей использования и адаптации лучшего мирового опыта в России рассмотрим наиболее известные ГЧП-агентства и их ключевые функции. С этой целью привлечем данные проведенных ранее исследований. Всемирный банк совместно с Консультативным центром по вопросам инфраструктуры и частного сектора (PPIAF) провел оценку эффективности ряда ГЧП-агентств [3, р. 7], ранжирование которых представлено на рисунке 1.

Наиболее эффективными и успешными признаются ГЧП-агентства Великобритании, Австралии и ЮАР, чем и был определен выбор этих стран в качестве объектов анализа. В сферу исследовательского интереса попали также агентства Индии и Канады. Примечательно, что 
ЮАР, Индия и Россия объединились в группу БРИКС, с чем связан особый интерес в исследовании агентств этих стран.

Успех внедрения ГЧП-проекта

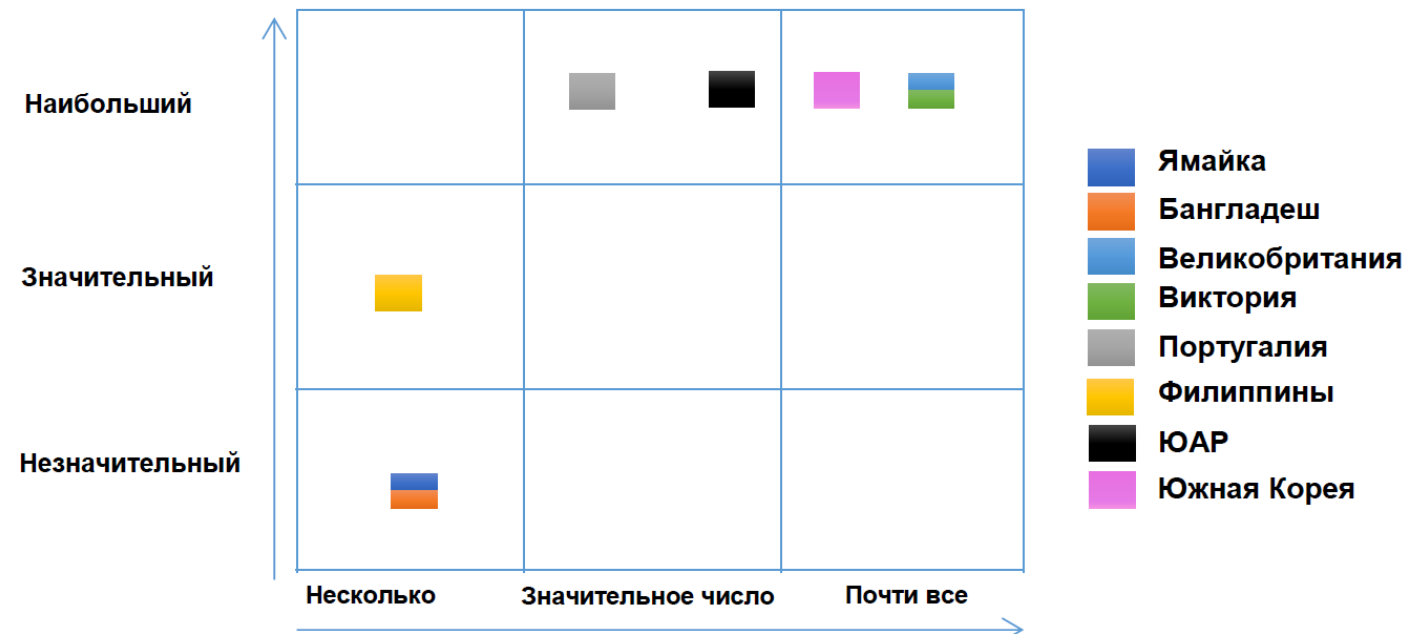

Количество возложенных на ГЧП-агентство функций

\section{Рисунок 1 - Эфффективность ГЧП-агентств разных стран в зависимости от количества возложенных на них фрункций [4]}

Агентства, осуществляющие управление ГЧП, можно классифицировать по разным признакам. Выделим среди них два: уровень управления и объем выполняемых функций. Первая классификация представлена в структуре статьи, вторая предполагает выделение агентств, выполняющих преимущественно контрольные функции, и полнофункциональных агентств с широким кругом полномочий, включая разработку стратегий развития и управления рынком ГЧП, предоставление консультационных услуг, сопровождение сделок, в некоторых случаях - финансирование. Индии

Модель института управления на национальном уровне: опыт Великобритании, ЮАР и

В июле 1997 г. в Казначействе Великобритании была создана Казначейская целевая группа (Treasury Taskforce - TTF) по реализации программы «Частная финансовая инициатива» (Private Finance Initiative - PFI). Главными задачами рабочей группы заявлены стандартизация процесса и обучение сотрудников правительства принципам PFI. Проектная команда TTF в 2000 г. стала называться Partnerships UK (PUK). В июне 2010 г. было создано Infrastructure UK (IUK) как отдельное подразделение в казначействе для работы с частным сектором в рамках реализации крупных инфрраструктурных проектов. В результате этого PUK в мае 2011 г. была упразднена. Большая часть активов, оказываемых услуг, данных и персонала перешла в ведение IUK.

Превращение рынка ГЧП Великобритании в один из самых развитых в мире привело к исчезновению необходимости в полнофункциональном агентстве PUK. IUK сохранила за собой функции координации, упрощения процесса планирования и приоритизации инвестиций в инфраструктуру Великобритании, развития инфраструктуры страны через достижение лучшего соотношения «цена - качество» в проектах.

Применительно к России целесообразно проанализировать опыт PUK, деятельность которой приходилась на ранние этапы становления рынка ГЧП в Великобритании. PUK выступала полноценной государственно-частной компанией, в которой контрольный пакет - $51 \%$ акций принадлежал частному сектору, 49 \% - государственному. PUK функционировала не как консультант правительства, а как интегрированное подразделение казначейства [5, с. 72]. PUK, имеющая свой собственный капитал, принимала собственные инвестиционные и операционные решения без согласования их с государственными органами. Во избежание конфрликта интересов частного и государственного секторов был создан Консультационный совет под руководством казначейства, членами которого являлись государственные служащие. Ограничены полномочия акционеров в части изменения миссии и деятельности PUK в целях максимизации прибыли, распределения дивидендов и назначения членов совета директоров из своих организаций. 
Деятельность PUK в основном фринансировалась за счет средств, получаемых от взимания платы за услуги, оказываемые государственным агентствам и департаментам, размер которой зависел от затрачиваемого на конкретный проект времени, причем суточная ставка согласовывалась на правительственном уровне. Определенный доход приносило консультирование правительств других стран, которым была необходима помощь в создании и реализации национальных ГЧП-программ и агентств.

Важнейшим фактором, обеспечившим успех PUK, было стремление всех заинтересованных сторон заботиться об интересах государства.

В апреле 1997 г. Кабинетом министров ЮАР было принято решение об организации подразделения South African PPP Unit (SA PPP Unit) для разработки нормативно-правовых актов, пакета программ и институциональных реформ в целях развития ГЧП в стране. В декабре 1999 г. были приняты основные принципы ГЧП, а в апреле 2000 г. разработаны инструкции и нормы казначейства в области ГЧП в рамках Акта об управлении государственными финансами. В середине 2000 г. в структуре казначейства было учреждено ГЧП-подразделение. В него вошли пять профеессионалов в области ГЧП из частного и государственного секторов. Вхождение в структуру казначейства обеспечивает доступ к фринансовым ресурсам, но более низкий уровень заработной платы, что препятствует привлечению профессиональных кадров.

Основными целями SA PPP Unit являются: поддержка национального казначейства и казначейств провинций в эффективном регулировании ГЧП, создание динамичного и эффеективного центра компетенций в области ГЧП, увеличение количества реализуемых ГЧП-проектов посредством поиска инвестиционных проектов с подходящим соотношением «цена - качество» для всех сторон, осуществление технической поддержки государственных органов в процессе реализации ГЧП-проектов, продвижение рынка ГЧП и создание благоприятной среды для его развития. Специалисты SA PPP Unit активно участвуют в разработке направлений и стандартов в области ГЧП, проводят тренинги [6].

Создание SA PPP Unit сопровождалось рядом фискальных реформ, в результате которых была закреплена определяющая роль казначейства в отборе ГЧП-проектов, инициируемых правительственными структурами. Юридически правительственные структуры могут стимулировать разработку технико-экономического обоснования проекта или начать привлекать инвесторов без участия SA PPP Unit и осуществления консультаций с ним. На практике правительственные организации прибегают к консультациям с SA PPP Unit, а инвесторы проявляют интерес к тем ГЧПпроектам, в которых участвует SA PPP Unit.

Для создания институциональной среды ГЧП Департаментом по экономическим вопросам Министерства финансов Индии был создан специализированный институт PPP Cell. В составе данного института в мае 2007 г. было образовано подразделение, выполняющее функции центрального агентства для реализации ГЧП-проектов, а именно: сбор информации о ГЧП-проектах, консультирование задействованных в проектах департаментов с применением передовых практик, методов, руководств, схем; координация задействованных в ГЧП-проектах департаментов на начальных этапах разработки проектов и контроль за их деятельностью на последующих этапах реализации; направление предложений правительству о мерах по поддержке проектов, осуществление поддержки правительств штатов в подготовке проектов; разработка и осуществление планирования ГЧП-проектов в штатах Индии в соответствии с ежегодным планом.

В последние годы функции PPP Cell расширились за счет включения функций: по использованию схем финансовой поддержки созданными фондами Viability Gap Funding (VGF) и India Infrastructure Project Development Fund (IIPDF); разработке и внедрению инновационных механизмов поддержки и продвижения ГЧП, включая использование программ технической поддержки многосторонних кредитных организаций; управлению программами обучения, стратегиями и развитием компетенций в области ГЧП.

B рамках VGF осуществляется финансирование проектов, предложенных национальными министерствами, правительствами штатов и другими государственными органами, на сумму до 2000 млн рупий в зависимости от бюджетных ограничений, определенных Министерством фринансов. Финансирование в рамках VGF возможно для проектов, в которых доля частного партнера превышает 51 \%. Средства VGF могут быть представлены в виде одноразового или поэтапных платежей, их сумма не должна превышать 20 \% капитальных затрат проекта. Дополнительное финансирование, не превышающее 20 \% капитальных затрат, может быть осуществлено министерством, реализующим проект. Средства представляются в форме инвестиционных субсидий на этапе строительства [7].

IIPDF предоставляет национальным министерствам и правительствам штатов средства на подготовку и разработку проектов (технико-экономическое обоснование, оценку влияния на окружающую среду, финансовое структурирование, юридические консультации). Это делается с тем, 
чтобы представленные частным инвесторам проекты имели высокую степень проработки и были более привлекательны. В рамках IIPDF компенсируется не более 75 \% всех затрат на подготовку проекта. Средства предоставляются в рамках беспроцентного займа. IIPDF является пополняемым фондом, средства в который возвращаются в виде «выплат за успех» по отобранным проектам, где эти средства включаются в общие затраты на проект. Чтобы воспользоваться финансированием через IIPDF, инициирующее проект министерство должно направить свою заявку в PPP Cell.

Модель смешанного института управления ГЧП на уровне правительства и провинций: опыт Канады и Австралии

ГЧП в Канаде первоначально возникло на уровне провинций, и лишь в 2008 г. появился национальный орган PPP Canada, что позволило сформировать модель смешанного управления ГЧП на уровне центрального правительства и провинций. PPP Canada является государственной корпорацией, обеспечивающей процесс создания инфраструктуры через механизм ГЧП, осуществляя поддержку участников, проводя экспертизу и используя наилучшие компетенции в оценке и структурировании сделок ГЧП. Кроме того, PPP Canada осуществляет соинвестирование в инфраструктуру провинций, территорий и муниципалитетов через P3 Canada Fund. PPP Canada не занимается нормативно-правовой работой [8].

PPP Canada проводит обучающие семинары для государственных работников из провинций, выпускает отчеты по широкому кругу инфраструктурных секторов с методическими рекомендациями и статистикой по рынку.

PPP Canada находится под контролем Министерства финансов и отчитывается парламенту. Совет директоров PPP Canada, состоящий из 9 человек, одобряет рекомендации для министерств. Министр финансов и руководитель казначейства разделяют ответственность в одобрении и изменении условий конкретных проектов, финансируемых фондом P3 Canada Fund. Финансовая поддержка проектов из фонда не должна превышать 25 \% стоимости проектов.

В Австралии инициатива по созданию органа управления ГЧП тоже исходила от штата. Partnerships Victoria (PV) является центром экспертизы в области ГЧП. Его роль заключается в разработке политики и стандартов обеспечения экономики штата Виктория инфраструктурой через механизмы ГЧП. Основными задачами PV выступают: разработка программы, стандартов ГЧП, консультирование в процессе реализации ГЧП-проектов по вопросам контроля и исполнения.

$\mathrm{PV}$ является отделом Коммерческого департамента казначейства и финансов Правительства Виктории. Нормы поведения и стандарты PV применяются всеми правительственными департаментами и агентствами, задействованными в инфраструктурных проектах. Ключевой целью данных стандартов является обеспечение последовательности и связанности действий правительственных структур [9].

Основным подходом в работе PV является то, что государственные органы должны покупать качественные инфраструктурные услуги в согласованном объеме, а не активы как таковые. Согласно стандартам PV краткосрочные контакты заменяются долгосрочными, авансовые платежи уступают место платежам по показателям текущей деятельности, входные параметры и требования по затратам заменяются на показатели и характеристики оказываемых услуг.

В декабре 2008 г. в Австралии был принят закон «Infrastructure Australia Act 2008», в соответствии с которым создано государственное учреждение «Инфраструктура Австралии», приняты национальная ГЧП-программа и стандарты, которые заменили программы и стандарты штатов и территорий.

Проведенный анализ позволил выявить следующие закономерности фрормирования и функционирования ГЧП-агентств:

1. ГЧП-агентство может создаваться либо как подразделение министерства финансов или казначейства, либо как компания. В первом случае преимуществами являются лучшая координация деятельности с государственными органами, отсутствие конфликта интересов между публичным и частным партнерами. Достоинства компании состоят в гибкости структурирования операционной деятельности, привлечении более квалифрицированных специалистов вследствие высокого уровня заработной платы, в большем доверии со стороны частного сектора.

2. В большинстве случаев агентства не имеют отраслевой направленности, однако бывают исключения. Например, Highways Agency (Великобритания) реализует проекты исключительно в области дорожного строительства, Transnet (ЮАР) контролирует сделки в области коммерческих железнодорожных перевозок, морских портов и трубопроводов.

3. Финансирование ГЧП-агентств в большинстве случаев осуществляется государством. Агентства, являющиеся самостоятельными компаниями, стремятся к независимости от государственного финансирования и осуществляют взимание платы за услуги.

4. Наиболее эфффективно реализуются проекты при поддержке многофункционального ГЧП-агентства с широкими полномочиями, имеющего технические и финансовые ресурсы. 
В России созданы похожие структуры, которые находятся в состоянии становления или реализованы в незначительном для размеров национальной экономики масштабе (табл. 1).

Таблица 1 - Органы управления ГЧП в России [10]

\begin{tabular}{|c|c|c|}
\hline Орган управления ГЧП & $\begin{array}{c}\text { Год } \\
\text { создания }\end{array}$ & Функции \\
\hline Центр ГЧП Внешэкономбанка & 2007 & $\begin{array}{l}\text { Квалифицированное обслуживание деятельности } \\
\text { органов государственного управления по примене- } \\
\text { нию инструментов ГЧП для реализации отраслевых } \\
\text { и региональных стратегий развития, по совершен- } \\
\text { ствованию таких инструментов }\end{array}$ \\
\hline НП «Центр развития ГЧП» & 2009 & $\begin{array}{l}\text { Сопровождение проектов, исследовательская дея- } \\
\text { тельность, экспертиза законодательства, подготовка } \\
\text { кадров, информационное сопровождение }\end{array}$ \\
\hline Институт развития ГЧП & 2012 & $\begin{array}{l}\text { Повышение квалификации и профессиональная пе- } \\
\text { реподготовка участников проектов ГЧП, разработка и } \\
\text { внедрение профессиональных и образовательных } \\
\text { стандартов в сфере ГЧП, реализация исследова- } \\
\text { тельских проектов в сфере ГЧП, развитие инфра- } \\
\text { структуры, проектного финансирования, формирова- } \\
\text { ние нормативно-правовой базы и пр. }\end{array}$ \\
\hline $\begin{array}{l}\text { ФКУ «Дирекция государствен- } \\
\text { ного заказчика по реализации } \\
\text { ФЦП “Модернизация транспорт- } \\
\text { ной системы России"» при цен- } \\
\text { тре ГЧП Минтранса РФ }\end{array}$ & 2004 & $\begin{array}{l}\text { Подготовка предложений Минтрансу РФ по привле- } \\
\text { чению инвесторов для реализации проектов на ос- } \\
\text { нове ГЧП, совершенствованию нормативной базы, } \\
\text { необходимой для реализации ФЦП «Развитие транс- } \\
\text { портной системы России (2010-2020 годы)», привле- } \\
\text { чению внебюджетных источников финансирования; } \\
\text { разработка и внедрение новых механизмов на ос- } \\
\text { нове моделей ГЧП }\end{array}$ \\
\hline $\begin{array}{l}\text { Координационный совет по ГЧП } \\
\text { при Минэкономразвития России }\end{array}$ & 2014 & $\begin{array}{l}\text { Совершенствование законодательства в сфере ГЧП, } \\
\text { разработка предложений по фрормированию и реали- } \\
\text { зации основных направлений государственной поли- } \\
\text { тики в сфере ГЧП, а также предложений по реализа- } \\
\text { ции системообразующих инфраструктурных проектов }\end{array}$ \\
\hline
\end{tabular}

В 2006 г. в структуре Внешэкономбанка был создан центр ГЧП, но претендовать на статус ядра системы управления ГЧП он не смог, так как, являясь структурой банка, занимался специфрическими вопросами фринансирования и его компетенции не могли быть распространены на решение методических, координационных проблем ГЧП в стране.

Универсальная роль транспорта как материального носителя территориально-экономических связей и выразителя производственного и пространственного разделения труда в такой большой стране, как Россия, поставила на первое место проблему развития его инфраструктуры, для чего в 2004 г. была создана некоммерческая организация ФКУ «Дирекция государственного заказчика по реализации ФЦП “Модернизация транспортной системы России”», находящаяся в ведении Министерства транспорта РФ и выполняющая функции центра ГЧП Министерства транспорта РФ.

Важную роль в координации деятельности сторон, участвующих в реализации ГЧП-проектов, призвано сыграть Министерство экономического развития РФ (МЭР). Для усиления этой роли в мае 2014 г. приказом № 279 МЭР России утвердило Положение о Координационном совете по государственно-частному партнерству при МЭР России, а в 2015 г. был принят Ф3 № 224 «О государственно-частном партнерстве, муниципально-частном партнерстве в Российской Федерации и внесении изменений в отдельные законодательные акты Российской Федерации». Предполагалось, что принятие указанного закона будет способствовать усилению этой роли, поскольку закон отражает концепцию либерального развития, в соответствии с которой частный капитал получает доступ в такие сферы экономики, которые были закрыты для бизнеса: инфраструктура, атомная энергетика, оборона, образование и здравоохранение.

Однако методические документы по проблемам ГЧП, размещенные на сайте министерства, подготовлены НП «Центр развития ГЧП». Единая информационная система ГЧП в Российской Федерации также создавалась этим центром. Структурой разработана концепция «Квалифицированный заказчик», на основании которой организация предоставляет следующие услуги: разработка проектов нормативно-правовых актов; предоставление типовых организационных документов; консультирование по вопросам, касающимся применения методологии управления проектами государственно-частного партнерства; создание специализированной организации, отвечающей за управление проектом. Центром развития ГЧП разработана «Концепция развития 
государственно-частного партнерства в РФ до 2020 года». В действительности в МЭР проблемами ГЧП занимается отдел с немногочисленным персоналом, а НП «Центр развития ГЧП» разрабатывает информационно-консультационные и методические проекты.

Одной из основных проблем реализации инфраструктурных ГЧП-проектов является привлечение финансирования. В соответствии с Бюджетным кодексом государство участвует в подобных проектах с использованием средств инвестиционных фондов, к которым относятся Инвестиционный фонд РФ и инвестиционные фонды субъектов РФ. Однако реально Инвестиционный фонд РФ выделяет средства на федеральные проекты начиная от 5 млрд р., на региональные от 500 млн р., пропуская при этом 1-2 проекта в год, что не позволяет говорить об эфффективном выполнении данной структурой функций института развития проектов ГЧП. В соответствии с поручениями правительства в декабре 2016 г. инвестиционный фонд был упразднен.

В марте 2017 г. было заявлено, что в рамках МЭР России планируется создание Координационного межотраслевого совета по вопросам ГЧП с участием основных участников рынка. В апреле 2017 г. МЭР РФ выступило с предложением создания фабрики проектного финансирования во Внешэкономбанке (ВЭБ) для реализации инфраструктурных проектов. В результате этих инициатив вырисовываются контуры многофункционального института развития (ГЧПагентства), который может сочетать в себе бизнес-планирование, структурирование и реализацию проектов, финансовое закрытие и постконтрактные услуги, подготовку и обучение специалистов в области ГЧП; анализ нормативно-правовых ограничений и подготовку рекомендаций для их устранения; контрольные и надзорные функции за ходом реализации проекта.

Особенностью ГЧП-агентства должна стать возможность инициации проектов со стороны не только государства, но и частного сектора. В процессе реализации проекта могут возникнуть разногласия по условиям сделок, агентство должно стать арбитром и гарантом исполнения обязательств, принятых сторонами сделки. В случае возникновения разногласий необходимо создание трехсторонних комиссий под руководством центра, решения которых должны исполняться вовлеченными сторонами. Обязанность исполнения подобных решений должна быть прописана в договорах во время структурирования сделок.

\section{Ссылки и примечания:}

1. Горяинова Л.В. Инфраструктурные услуги в концепции опекаемых благ // Теория и практика общественного развития. 2015. № 6. C. 43-47.

2. Farrugia C., Reynolds T., Orr R.J. Public-Private Partnership Agencies: A Global Perspective / Collaboratory for Research on Global Projects. Stanford, 2008. P. 5.

3. Public-Private Partnership Units: Lessons for their Design and Use in Infrastructure / The World Bank, PPIAF. Washington D.C., 2007. P. 7.

4. Рисунок 1 составлен автором по материалам Всемирного банка и Консультативного центра по вопросам инфраструктуры и частного сектора.

5. Йескомб Э.Р. Государственно-частное партнерство: основные принципы финансирования : пер. с англ. М., 2015. 457 с.

6. South African Public Private Partnership Unit [Электронный ресурc]. URL: http://www.ppp.gov.za/Pages/About.aspx (дата обращения: 16.06.2017).

7. Public Private Partnership Cell [Электронный ресурc]. URL: http://www.ppp.punjab.gov.pk/functions (дата обращения: 16.06.2017).

8. Delivering Value for Taxpayers [Электронный pecypc] : PPP Canada annual report, 2012-2013. URL: http://www.p3canada.ca/ /media/english/annual-reports/files/2012-2013\%20annual\%20report.pdf (дата обращения: 14.06.2017).

9. Partnerships Victoria - Excellence in Public Private Partnerships [Электронный pecypc]. 2017. URL: http://www.dtf.vic.gov.au/Infrastructure-Delivery/Public-private-partnerships/Partnerships-Victoria-Excellence-in-public-private-partnerships (дата обращения: 14.07.2017).

10. Таблица 1 составлена автором.

\section{References:}

Delivering Value for Taxpayers: PPP Canada annual report, 2012-2013 2017, viewed 14 June 2017, <http://www.p3canada.ca/ /media/english/annual-reports/files/2012-2013\%20annual\%20report.pdf>.

Farrugia, C, Reynolds, T \& Orr, RJ 2008, Public-Private Partnership Agencies: A Global Perspective, Collaboratory for Research on Global Projects, Stanford, p. 5.

Goryainova, LV 2015, 'Infrastructure services in the conception of subsidized goods', Teoriya i praktika obshchestvennogo razvitiya, no. 6, pp. 43-47, (in Russian).

Partnerships Victoria - Excellence in Public Private Partnerships 2017, viewed 14 July 2017, <http://www.dtf.vic.gov.au//nfrastructure-Delivery/Public-private-partnerships/Partnerships-Victoria-Excellence-in-public-private-partnerships > .

Public Private Partnership Cell 2017, viewed 16 June 2017, <http://www.ppp.punjab.gov.pk/functions>.

Public-Private Partnership Units: Lessons for their Design and Use in Infrastructure 2007, The World Bank, PPIAF, Washington D.C., p. 7.

South African Public Private Partnership Unit 2017, viewed 16 June 2017, <http://www.ppp.gov.za/Pages/About.aspx>. Yescombe, ER 2015, PPP: principles of policy and finance, Moscow, 457 p., (in Russian). 